\title{
Potensi daging buah pisang dan kulit pisang (Musaceae) untuk peningkatan kualitas roti dan kue
}

Potential of banana pulp and banana peel (Musaceae) to improve the quality of bread and cake

\author{
Fransisca Krista Arinta ${ }^{1}$, Franciscus Sinung Pranata ${ }^{1}$, Yuliana Reni Swasti ${ }^{1}$ \\ ${ }^{1}$ Fakultas Teknobiologi, Universitas Atma Jaya Yogyakarta \\ *E-mail korespondensi: sinung.pranata@uajy.ac.id
}

Informasi Artikel:

Dikirim: 12/01/2021; disetujui: 20/07/2021; diterbitkan: 20/09/2021

\begin{abstract}
Banana is a plant that grows in a several countries, particularly in Indonesia. Since banana is susceptible to mechanical damage and has a short shelf life, thus banana need to be processed into flour. Dietary fiber, starch, vitamins, minerals, and antioxidants can all be contained in banana flesh and skin. The aim of this Literature Review is to evaluate the potential of banana pulp and banana peels to improve the quality of bread and cakes. The Literature Review examines and evaluates research findings related to the potential of banana flesh and banana peels to improve the quality of bread and cakes using a narrative method. The best increase in fiber content in banana peel flour on cukke cake was $8.5 \%$ when bread and cake products with fruit pulp and banana peel flour were combined. The best sensory properties were 5,63 \pm

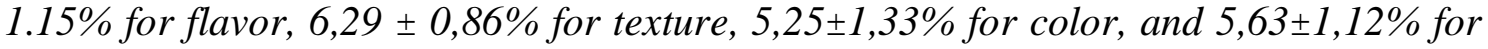
overall, especially muffin products (banana pulp and banana peel). The best outcome of raising bread volume on Mantou banana flesh was $6,77 \pm 0,63 \mathrm{~mL} / \mathrm{g}^{1}$. To maintain the sensory and physical properties of bread and cakes, banana flour (including flesh and peel) can be applied to food products at a concentration of 10-15\%.
\end{abstract}

Keywords: banana flesh, banana peel, fiber, bread, cake

\begin{abstract}
ABSTRAK
Pisang merupakan tanaman yang dapat dijumpai di beberapa negara terutama di Indonesia. Buah pisang rentan terhadap kerusakan mekanis dan daya simpan rendah, sehingga perlu diolah menjadi tepung. Daging buah pisang dan kulitnya, memiliki kandungan serat pangan, pati, vitamin, mineral dan antioksidan. Tujuan Literature Review ini untuk mengevaluasi mengenai potensi daging buah pisang dan kulit pisang untuk peningkatan kualitas roti dan kue. Penelitian Literature Review menggunakan metode naratif yang mengkaji dan menganalisis hasil penelitian terkait potensi daging buah pisang dan kulit pisang untuk peningkatan kualitas roti dan kue. Produk roti dan kue dengan penambahan tepung daging buah maupun kulit pisang memberikan hasil peningkatan kandungan serat terbaik pada tepung kulit pisang pada bolu cukke sebesar $8,5 \%$. Hasil terbaik pada sifat sensori rasa sebesar 5,63 $\pm 1,15 \%$, tekstur sebesar $6,29 \pm 0,86 \%$, warna sebesar $5,25 \pm 1,33 \%$ dan keseluruhan sebesar $5,63 \pm 1,12 \%$ yaitu produk muffin daging buah dan kulit pisang. Hasil terbaik peningkatan volume roti pada Mantou daging buah pisang sebesar $6,77 \pm 0,63 \mathrm{~mL} / \mathrm{g}^{1} \%$. Tepung pisang (daging buah maupun kulit) dapat diaplikasikan pada produk pangan dengan konsentrasi 10-15\% untuk menjaga sifat sensori dan fisik roti dan kue.
\end{abstract}

Kata Kunci: daging buah pisang, kulit pisang, serat, roti, kue 


\section{PENDAHULUAN}

Produk bakery yang dikenal luas dan sudah menjadi bagian konsumsi sehari - hari masyarakat antara lain roti dan kue. Pembuatan roti dan kue menggunakan bahan dasar tepung gandum. Warna tepung putih berasal dari pengolahan biji-biji gandum utuh yang diproses, sehingga menyebabkan zat gizi yang terkandung akan menurun(Baba et al., 2015).

Saat ini kebutuhan manusia akan pangan yang berkualitas tinggi dan sehat atau disebut pangan fungsional mengalami peningkatan (Baba et al., 2015). Salah satu bahan pangan yang berpotensi untuk digunakan adalah pisang. Pemanfaatan daging buah maupun kulit pisang sebagai substitusi tepung gandum diharapkan dapat memberikan nilai gizi tambahan pada produk makanan (Salih et al., 2017).

Daging buah pisang mentah memiliki kandungan pati yang tinggi, sedangkan untuk daging buah pisang matang memiliki kandungan gula yang tinggi untuk memberikan cita rasa yang manis pada produk makanan (Salih et al., 2017). Pisang (Musaceae) sebagai sumber energi yang kaya akan karbohidrat sebesar 22-32\% dari bobot daging buah. Selain itu, daging pisang kaya akan vitamin $\mathrm{A}$, B6 dan $\mathrm{C}$ juga mineral khususnya kalium, magnesium, fosfor dan folat (Adebayo-Oyetoro, Ogundipe dan Adeeko, 2016). Kulit pisang menyumbang $47-50 \%$ dari berat total daging buah pisang, namun penggunaan kulit pisang di industri pangan belum banyak dilakukan, biasanya hanya dimanfaatkan sebagai pakan ternak maupun pupuk (Gomes, Ferreira dan Pimental, 2016).

Menurut statistik FAO, Asia merupakan penghasil pisang terbesar yaitu $54,4 \%$ dari produksi dunia dan rata-rata konsumsi pisang sebesar $12 \mathrm{~kg}$ per kapita (Khoozani, Birch dan Bekhit, 2020), namun dari total produksi, sekitar $40 \%$ hilang hanya pada masa pascapanen (Gomes, Feerira, Pimentel, 2016). Pengolahan pisang (daging buah maupun kulitnya) menjadi tepung dapat meningkatkan masa simpan (Hardisari dan
Amaliawati, 2016). Tujuan dari penulisan Literature Review ini adalah untuk mengevaluasi mengenai potensi daging buah pisang dan kulit pisang untuk peningkatan kualitas roti dan kue terhadap kualitas kimia, sensori dan fisik.

\section{ISI}

\section{Roti dan kue}

Produk bakery telah dikonsumsi secara luas seperti produk roti dan kue (Malik et al., 2006). Roti adalah adonan yang dipanggang hasil dari campuran tepung, garam, gula, ragi dan air serta bahan tambahan lainnya seperti lemak, susu, telur, dan bahan yang dapat ditambahkan (Adebayo-Oyetoro, Ogundipe dan Adeeko, 2016), sedangkan kue adalah produk makanan manis yang mengandung lebih banyak gula (Malik et al., 2006). Proses pembuatan roti terdiri dari pencampuran bahan, menguleni menjadi adonan, mengistirahatkan adonan untuk proses fermentasi (proofing), pembentukan adonan dan pemanggangan (Baba et al., 2015). Pembuatan kue dilakukan dengan mengocok mentega dan gula untuk menghasilkan busa ringan, penambahan susu bubuk skim, tepung terigu, telur, soda kue, baking powder, penambahan air, lalu formulasi adonan cair, kemudian adonan cair ditempatkan di dalam wadah dan dioven (Malik et al., 2006).

\section{Pisang dan kandungan zat gizi pisang}

\subsection{Jenis pisang}

Di berbagai negara terdapat beragam varietas tumbuhan pisang, yang sebagian tumbuh di daerah tropis Asia, IndoMalaysia, Australia dan diseluruh negara tropis dan subtropis seperti Brazil, India, Filipina, dan Thailand (Imam dan Akter, 2011). Pisang umumnya terdiri dari sejumlah spesies dalam genus Musa dari famili Musaceae (Khoozani, Birch dan Bekhit, 2020). Genus Musa dibagi menjadi 4 bagian berdasarkan jumlah kromosom yaitu Eumusa, Rhodochlamys, Australimusa dan Callimusa. Emusa merupakan bagian terbesar dan paling luas penyebaran. Beberapa spesies dari Emusa adalah Musa acuminata Colla atau Musa cavendishii, Musa paradisiaca dan Musa 
sapientum, sedangkan untuk Australimus salah satu spesiesnya adalah Musa troglodytarum L. yaitu Pisang Fe'i (Pereira dan Maraschin, 2015).

\subsection{Daging buah pisang dan kulit pisang}

Daging buah dan kulit pisang mengandung mineral berupa natrium, kalium, kalsium, zink, mangan, rubidium, tembaga, fosfor, magnesium dan besi. Kandungan mineral yang paling tinggi adalah kalium (Khoozani, Birch dan Bekhit, 2020). Selain itu juga terdapat kandungan vitamin C, B, A, dan E (Khoozani Birch dan Bekhit, 2019). Kandungan serat pangan pada pisang berupa lignin, selulosa (Moniharapon, Picauly dan Lelmalaya, 2018), pektin (0,71,2\%) (Mohapatra, Mishra dan Sutar, 2010), hemiselulosa (Segundo et al., 2017), inulin sekitar $\pm 1 \mathrm{~g} / 100 \mathrm{~g}$ dan frukto-oligosarida (FOS) (Hardisari dan Amaliawati, 2016). Kulit pisang memiliki kadar serat pada bagian lignin $(6-12 \%)$, selulosa $(7,6-9,6 \%)$ pektin (10-21\%), dan hemiselulosa (6,49,4\%) (Mohapatra, Mishra dan Sutar, 2010).

\section{Tepung pisang (daging buah dan kulit)}

\subsection{Pra perlakuan pembuatan tepung pisang}

Daging buah pisang dan kulit pisang dapat dimanfaatkan dan diolah menjadi tepung untuk bahan pangan, sehingga dapat meningkatkan masa simpan (Hardisari dan Amaliawati, 2016). Sebelum proses pengeringan pisang, perlakuan awal yang dapat dilakukan untuk mengurangi reaksi pencokelatan pada tepung yaitu dilakukan proses pemanasan, melakukan perendaman kulit pisang dengan menggunakan natrium metabisulfit, asam sitrat, asam askorbat sebagai inhibitor pencokelatan kimia (Tabel 1).

Proses pemanasan pada pisang efektif dapat menghambat pencokelatan pada pisang, namun pemberian perlakuan gabungan antara metabisulfit dan asam askorbat merupakan metode yang paling efektif (Guessan, Kouadio dan Gonnety, 2018). Asam askorbat mereduksi kembali okuinon yang terbentuk menjadi senyawa difenol dan asam askorbat akan melepaskan 2 molekul hidrogennya dengan membentuk dehidroasam askorbat. Terbentuknya senyawa fenol kembali akan menyebabkan pembentukan melanin dari kuinon tidak berlangsung (Mardiah, 2011)

Mekanisme natrium metabisulfit yaitu inhibisi searah reaksi enzimatik, dan pembentukan produk tambahan antara sulfite dan o-kuinon, sehingga membalikan arah reaksi enzimatik (Wardhani, Yuliana dan Dewi, 2016). Daging buah pisang yang masih mentah (kulit pisang hijau) menghasilkan warna tepung kuning pucat (cream) dan matang (kuning) memiliki warna tepung cokelat muda (Alkarkhi et al., 2011). Kulit pisang menghasilkan warna tepung kecokelatan (Aryani, Mu'awanah dan Widyantara, 2020).

Tabel 1. Indeks pencokelatan pada pemberian perlakuan pisang

\begin{tabular}{cccc}
\hline Perlakuan & $\begin{array}{c}\text { Konsentrasi } \\
(\mathrm{mg} / 100 \mathrm{~g})\end{array}$ & $\begin{array}{c}\text { Indeks } \\
\text { Pencokelatan }\end{array}$ & Sumber \\
\hline Kontrol & 0 & $43,3 \pm 0,5^{5}$ & \\
Metabisulfit dan asam askorbat & $5: 50$ & $9,5 \pm 1,2^{2}$ & Guessan \\
& $7: 50$ & $4,9 \pm 0,7^{1}$ & Kouadio dan \\
Pemanasan $60^{\circ} \mathrm{C} ; 35$ menit + asam & $40: 50$ & $13,9 \pm 0,7^{4}$ & Gonnety, 2018 \\
sitrat dan asam askorbat & $50: 50$ & $11,8 \pm 0,1^{3}$ & \\
\hline
\end{tabular}

$\overline{\text { Keterangan: Angka superscript yang berbeda pada kolom yang sama menunjukkan perbedaan }}$ yang signifikan $(\alpha=5 \%)$ 
3.2. Pembuatan tepung pisang (daging buah dan kulit)

Tabel 2. Hasil Tepung dengan Metode Oven dan Freeze Drying

\begin{tabular}{cccc}
\hline Parameter & Metode Oven & Metode Freeze Drying & Sumber \\
\hline Kelembaban & $5,09 \mathrm{~g} / 100 \mathrm{~g}^{1}$ & $5,27 \mathrm{~g} / 100 \mathrm{~g}^{1}$ & Khoozani et al., \\
Karbohidrat & $84,62 \mathrm{~g} / 100 \mathrm{~g}^{1}$ & $84,61 \mathrm{~g} / 100 \mathrm{~g}^{1}$ & 2020 \\
Protein & $4,17 \mathrm{~g} / 100 \mathrm{~g}^{1}$ & $3,97 \mathrm{~g} / 100 \mathrm{~g}^{1}$ & Vu, Scarlett dan \\
Indeks Pencokelatan & $105,41 \pm 3,59^{2}$ & $53 \pm 1,09^{1}$ & Vuong, 2017 \\
\hline
\end{tabular}

Keterangan: Angka superscript yang berbeda pada baris yang sama menunjukkan perbedaan yang signifikan $(\alpha=5 \%)$

Proses pembuatan tepung dengan metode oven dilakukan dengan cara pisang (daging buah maupun kulit) dicuci terlebih dahulu, lalu ditiriskan dan dicelupkan ke dalam senyawa atau dilakukan pemanasan untuk mengurangi pencokelatan. Daging buah maupun kulit pisang di potongan setebal $2 \mathrm{~mm}$ (Khoozani et al., 2020). Pisang dikeringkan dengan menggunakan oven pada suhu suhu $60^{\circ} \mathrm{C}$ selama 24 jam, selanjutnya hasil yang sudah kering digiling dan diayak (Alkarkhi et al., 2011).

Metode freeze drying dilakukan dengan tahapan pisang (daging buah dan kulitnya) dicuci terlebih dahulu, dicelupkan ke dalam senyawa atau dilakukan pemanasan untuk mengurangi pencokelatan. Pisang dipotongpotong lalu diletakkan diatas nampan stainless dan ditempatkan di dalam air blast freezer pada suhu $-30^{\circ} \mathrm{C}$ selama 4 jam kemudian dipindahkan ke dalam freeze-dryer dan dikeringkan selama 48 jam. Pisang lalu digiling dan diayak (Khoozani, Birch dan Bekhit, 2020). Produk tepung pisang menunjukkan kandungan gizi yang tidak berbeda jauh antara metode oven dan metode freeze drying. Hasil indeks pencokelatan pada tepung menunjukkan bahwa penggunaan metode freeze drying memiliki hasil indeks pencokelatan yang lebih rendah dibandingkan dengan metode oven $(\mathrm{Vu}$, Scarlett dan Vuong, 2017).

\section{Kandungan gizi pada tepung daging buah pisang dan kulit pisang}

Pisang sebagai buah klimaterik akan mengalami proses pematangan seperti perubahan warna kulit, pati yang dikonversi menjadi gula, hilangnya rasa getir dan perubahan komposisi gizi (Adi, Oduro dan Tortoe, 2019). Namun tahap pematangan tidak mempengaruhi kandungan kimia dari jenis pisang secara konsisten (Emaga et al., 2008). Beberapa komposisi kandungan gizi tepung daging buah dan kulit pisang disajikan pada Tabel 3 .

Tabel 3. Komposisi kandungan gizi tepung daging buah dan kulit pisang

\begin{tabular}{cccccc}
\hline \multirow{2}{*}{ Parameter } & \multicolumn{2}{c}{ Daging Buah } & \multicolumn{2}{c}{ Kulit Buah } & \multirow{2}{*}{ Sumber } \\
\cline { 2 - 5 } & Mentah & Matang & Mentah & Matang & \\
\hline Serat Pangan (\%) & 15,5 & 18,99 & 43,68 & 50,84 & Ramli et al., 2009 \\
Pati Resisten (\%) & 52,88 & 12,19 & 8,57 & 2,58 & \\
Kalsium (mg/100g) & 140 & 16,8 & 50 & 43,3 & \\
Kalium (mg/100g) & 376,6 & 316,6 & 303,3 & 300 & \\
Vitamin C (mg/100g) & 0,09 & 0,09 & 0,09 & 0,18 & \multirow{2}{*}{ Salih et al., 2017 } \\
Total Gula (\%) & 3,21 & 13 & 4 & 15 & \\
Flavonoid (mg CE/100g) & 281,18 & 196,45 & 389,33 & 225,01 &
\end{tabular}

Tepung pisang dapat diolah dengan menggunakan pisang yang masih mentah dan matang. Tepung pisang mentah mengandung pati resisten dan vitamin yang lebih tinggi dibandingkan dengan tepung pisang matang, sehingga akan memberikan keuntungan terkait komponen yang tidak dapat dicerna seperti pati resisten. Tepung pisang matang 
memiliki kandungan gula yang tinggi dibandingkan dengan tepung pisang mentah, sehingga dapat memberikan cita rasa yang manis pada produk makanan (Salih et al., 2017). Serat pangan atau dietary fiber merupakan karbohidrat (polisakarida) dan lignin yang tidak dapat dihidrolisis oleh enzim pencernaan manusia, sehingga akan sampai di usus besar (kolon) dalam keadaan utuh (Aryani, Mu'awanah dan Widyantara, 2020). Menurut Institute of Medicine menyarankan asupan serat harian untuk masyarakat berdasarkan kategori umur berkisar antara 19 gram hingga 38 gram per hari (Quagliani dan Felt-Gunderson, 2017) (Tabel 4).

Tabel 4. Rekomendasi asupan serat harian oleh Insitute of Medicine

\begin{tabular}{ccc}
\hline & Umur (tahun) & Serat Pangan DRI (g/d) \\
\hline Anak-anak & $1-3$ & 19 \\
& $4-8$ & 25 \\
Wanita & $9-13$ & 26 \\
& $14-18$ & 26 \\
& $19-50$ & 25 \\
Laki-Laki & $50+$ & 21 \\
& $9-13$ & 31 \\
& $14-18$ & 38 \\
& $19-50$ & 38 \\
& $50+$ & 30 \\
\hline
\end{tabular}

Keterangan : DRI : Dietary Reference Intake (Referensi asupan Diet)

*Asupan yang mencukupi untuk serat yaitu $14 \mathrm{~g} / 1000 \mathrm{kcal}$ asupan per hari

\subsection{Serat pangan tidak larut pada daging buah dan kulit pisang}

Selulosa merupakan komponen dinding sel utama pada tumbuhan dengan rantai linier tidak bercabang polimer glukosa dengan ikatan $\beta-1,4 \quad$ glikosidik. Hemiselulosa merupakan polisakarida dinding sel yang larut oleh larutan alkali setelah menyerap air dan polisakarida pektin dan memiliki gugus glukosa dengan ikatan $\beta-1,4$ glikosidik namun berbeda dengan selulosa karena memiliki ukuran yang lebih kecil dan memiliki variasi gula serta umumnya bercabang. Lignin merupakan dinding sel non karbohidrat. Kompleks polimer fenil propana ikatan silang (Dhingra et al., 2012).

Serat pangan tidak larut dalam saluran pencernaan manusia tidak akan larut dalam air dan tidak membentuk gel. Serat tidak larut akan meningkatkan massa feses, ekskresi asam empedu dan menurunkan waktu transit pada usus, serta mengurangi potensi zat sitotoksik melalui penenceran zat di dalam usus besar. Serat makanan tidak larut lebih banyak terdapat dalam makanan dibandingkan dengan serat pangan larut (Mudgil, 2017).

\subsection{Serat pangan tidak larut pada daging buah dan kulit pisang}

Pektin merupakan kelompok

polisakarida kompleks dengan asam Dgalakturonat penysusun utamanya (Dhingra et al., 2012). FOS tersusun atas 2-10 unit monomer fruktosa dengan ikatan $\beta-(2-1)$ glikosidik dan satu monomer glukosa dengan ikatan $\alpha-(2-1)$ glikosidik pada ujungnya (Yuliana, Kusdiyantini dan Izzati, 2014). Inulin merupakan polisakarida yang mengandung glukosa, fruktosa, sukrosa dan polisakarida (Hardisari dan Amaliawati, 2016). Salah satu serat pangan yang juga penting dalam pisang yaitu pati resisten yang merupakan fraksi pati yang dapat mengatur luminal pencernaan yang secara khusus mengatur proses pencernaan menjadi lebih lambat karena tahan terhadap hidrolisis enzim di pencernaan (Segundo et al., 2017). Tepung pisang memiliki pati resisten tipe II yang akan diubah menjadi pati resisten tipe III selama proses pemanggangan atau pendinginan (Segundo et al., 2020).

Serat pangan larut bersifat prebiotik akan melewati proses pencernaan di dalam usus halus, sehingga mudah difermentasi 
oleh mikroflora usus besar menghasilkan asam lemak rantai pendek (SCFA). Serat larut yang telah larut air dapat memiliki efek viskositas yang akan membentuk gel kental, menyebabkan penurunan respon glikemik . Selain itu, membantu dalam meningkatkan waktu transit, sehingga penyerapan glukosa menjadi lebih lambat (Mudgil, 2017).
5. Pengaruh penambahan tepung pisang (daging buah dan kulit) pada pengujian kimia, sensori, dan fisik produk roti dan kue

\subsection{Pengaruh penambahan tepung pisang (daging buah dan kulit) pada pengujian kimia produk roti dan kue}

Pengaruh penambahan tepung pisang (daging maupun kulit) terhadap kandungan nutrisi disajikan pada Tabel 5.

Tabel 5. Pengaruh penambahan tepung pisang terhadap sifat kimia roti dan kue

\begin{tabular}{|c|c|c|c|c|c|c|}
\hline Tepung & Produk & $\begin{array}{c}\text { Kadar } \\
(\%)\end{array}$ & $\begin{array}{c}\text { Total Serat } \\
\text { Pangan } \\
(\text { g/100 } \\
\text { g atau \%) }\end{array}$ & $\begin{array}{c}\text { Pati } \\
\text { Resisten } \\
(\%)\end{array}$ & $\begin{array}{c}\text { Polifeno } \\
\text { l (mg } \\
\text { GA } \\
\text { /100 g) }\end{array}$ & Sumber \\
\hline \multirow{5}{*}{$\begin{array}{l}\text { Daging } \\
\text { buah dan } \\
\text { Kulit }\end{array}$} & \multirow{3}{*}{$\begin{array}{l}\text { Roti } \\
\text { Pang- } \\
\text { gang }\end{array}$} & 0 & $10,20 \pm 0,70^{3}$ & NT & NT & \multirow{3}{*}{$\begin{array}{l}\text { Gomes, Ferreira dan } \\
\text { Pimentel, } 2016\end{array}$} \\
\hline & & 10 & $12,86 \pm 0,83^{2}$ & NT & NT & \\
\hline & & 20 & $17,03 \pm 0,92^{1}$ & NT & NT & \\
\hline & \multirow[b]{2}{*}{ Muffin } & 0 & $3,86^{2}$ & $0,67^{2}$ & NT & \multirow{2}{*}{$\begin{array}{c}\text { Soto-Maldonado, } \\
\text { Concha-Olmos dan } \\
\text { Zuniga-Hasen, } 2020\end{array}$} \\
\hline & & 50 & $9,48^{1}$ & $0,98^{1}$ & NT & \\
\hline \multirow{2}{*}{$\begin{array}{l}\text { Daging } \\
\text { Buah }\end{array}$} & $\begin{array}{l}\text { Brown- } \\
\quad \text { ies }\end{array}$ & $\begin{array}{c}0 \\
25 \\
50 \\
75\end{array}$ & $\begin{array}{l}6,1^{2} \\
7,6^{1} \\
7,7^{1} \\
7,8^{1}\end{array}$ & $\begin{array}{l}\text { NT } \\
\text { NT } \\
\text { NT } \\
\text { NT }\end{array}$ & $\begin{array}{l}\text { NT } \\
\text { NT } \\
\text { NT } \\
\text { NT }\end{array}$ & $\begin{array}{l}\text { Moniharapon, } \\
\text { Picauly dan } \\
\text { Lelmalaya, } 2018\end{array}$ \\
\hline & $\begin{array}{l}\text { Sponge } \\
\text { Cake }\end{array}$ & $\begin{array}{c}0 \\
20 \\
40\end{array}$ & $\begin{array}{l}0,28^{3} \\
0,56^{2} \\
0,81^{1}\end{array}$ & $\begin{array}{l}\text { NT } \\
\text { NT } \\
\text { NT }\end{array}$ & $\begin{array}{l}20,26^{3} \\
49,08^{2} \\
77,70^{1}\end{array}$ & $\begin{array}{l}\text { Segundo et al., } \\
2017\end{array}$ \\
\hline Kulit & $\begin{array}{l}\text { Bolu } \\
\text { cukke }\end{array}$ & $\begin{array}{c}0 \\
10\end{array}$ & $\begin{array}{l}12,46^{2} \\
20,96^{1}\end{array}$ & $\begin{array}{l}\text { NT } \\
\text { NT }\end{array}$ & $\begin{array}{l}\text { NT } \\
\text { NT }\end{array}$ & $\begin{array}{c}\text { Manjilala, } \\
\text { Ekariskawati dan } \\
\text { Ipa, } 2019\end{array}$ \\
\hline
\end{tabular}

Keterangan: Angka superscript yang berbeda pada baris yang sama menunjukkan perbedaan yang signifikan $(\alpha=5 \%)$.

Penggunaan tepung daging buah dan kulit pisang belum matang pada produk roti panggang meningkatkan kadar serat pangan produk roti panggang sebesar $6,83 \%$ dibandingkan kontrol (Gomes, Ferreira dan Pimentel, 2016), sedangkan untuk produk muffin dengan menggunakan tepung daging buah dan kulit pisang terlalu matang mengalami peningkatan sebesar 5,62\% dan pati resisten sebesar 0,31\% dibandingkan dengan kontrol (Soto-Maldonado, ConchaOlmos dan Zuniga-Hansen, 2020). Penggunaan tepung daging buah pisang matang meningkatkan kadar serat pangan pada produk brownies sebesar 1,7\% (Moniharapon, Picauly dan Lelmalaya, 2018), sedangkan untuk produk sponge cake sebesar 0,53\% (Segundo et al., 2017). Penggunaan tepung pisang matang akan meningkatkan kadar total gula pada produk karena karbohidrat yang terkandung dalam buah pisang akan terhidrolisis menjadi gula sederhana (Moniharapon, Picauly dan Lelmalaya, 2018). Penggunaan tepung kulit pisang meningkatkan kadar serat pangan produk bolu cukke sebesar 8,5\% 
dibandingkan kontrol (Manjilala, Ekarisakawati dan Ipa, 2019).

Konsumsi produk diperlukan untuk memenuhi kebutuhan serat per hari wanita pada masing- masing produk yaitu untuk roti panggang sebesar 1,5 potong muffin 5 potong, brownies 3 potong, sponge cake 25 potong dan bolu cukke 1 potong. Kebutuhan serat per hari pria untuk roti panggang sebesar 2 potong, muffin 8 potong potong. brownies 5 potong, sponge cake 38 potong. dan bolu cukke sebesar 2 potong. Hal ini disesuaikan dengan rekomendasi asupan serat harian untuk wanita sebesar $25 \mathrm{~g} / \mathrm{hari}$ dan pria sebesar $38 \mathrm{~g} /$ hari (Quagliani dan Felt-Gunderson, 2017).

\subsection{Pengaruh penambahan tepung pisang} (daging buah dan kulit) pada pengujian sensori produk roti dan kue

Pengaruh penambahan tepung pisang (daging maupun kulit) terhadap kandungan nutrisi disajikan pada Tabel 6

Tabel 6. Pengaruh penambahan tepung pisang terhadap sifat sensori roti dan kue

\begin{tabular}{|c|c|c|c|c|c|c|c|c|}
\hline $\begin{array}{c}\text { Te- } \\
\text { pung }\end{array}$ & Produk & $(\%)$ & $\begin{array}{l}\text { Nilai } \\
\text { Kesukaa } \\
\text { n }\end{array}$ & Rasa & Tekstur & $\begin{array}{c}\text { War- } \\
\text { na }\end{array}$ & $\begin{array}{c}\text { Keseluruh } \\
\text {-an }\end{array}$ & Sumber \\
\hline Daging & \multirow{3}{*}{$\begin{array}{l}\text { Roti Pang- } \\
\text { gang }\end{array}$} & 0 & \multirow{3}{*}{$1-9$} & $7,93 \pm 1,09^{1}$ & $7,91 \pm 1,15^{1}$ & NT & $8,17 \pm 1,02^{1}$ & Gomes, \\
\hline $\begin{array}{l}\text { buah } \\
\text { dan }\end{array}$ & & 10 & & $7,96 \pm 1,24^{1}$ & $8.00 \pm 1,53^{1}$ & NT & $8.10 \pm 1,02^{1}$ & $\begin{array}{c}\text { Ferreira } \\
\text { dan }\end{array}$ \\
\hline Kulit & & 20 & & $7,73 \pm 1,41^{1}$ & $7,79 \pm 1,34^{1}$ & NT & $7.79 \pm 1,34^{1}$ & $\begin{array}{c}\text { Pimentel, } \\
2016\end{array}$ \\
\hline
\end{tabular}

Lanjutan Tabel 6. Pengaruh penambahan tepung pisang terhadap sifat sensori roti dan kue

\begin{tabular}{|c|c|c|c|c|c|c|c|c|}
\hline $\begin{array}{l}\text { Te- } \\
\text { pung }\end{array}$ & Produk & $(\%)$ & $\begin{array}{l}\text { Nilai } \\
\text { Kesuka- } \\
\text { an }\end{array}$ & Rasa & Tekstur & $\begin{array}{c}\text { War- } \\
\text { na }\end{array}$ & $\begin{array}{l}\text { Keseluruh- } \\
\text { an }\end{array}$ & Sumber \\
\hline \multirow[b]{2}{*}{$\begin{array}{c}\text { Daging } \\
\text { buah dan } \\
\text { Kulit }\end{array}$} & \multirow[b]{2}{*}{ Muffin } & 0 & \multirow[b]{2}{*}{$1-6$} & $5,21 \pm 1,08$ & $5,08 \pm 1,13$ & $\begin{array}{c}6,42 \pm 1 \\
07\end{array}$ & $6,27 \pm 0,92$ & $\begin{array}{c}\text { Soto- } \\
\text { Maldonado, }\end{array}$ \\
\hline & & 50 & & $5,63 \pm 1,15$ & $6,29 \pm 0,86$ & $\begin{array}{c}5,25 \pm 1 \\
33\end{array}$ & $5,63 \pm 1,12$ & $\begin{array}{c}\text { Concha- } \\
\text { Olmos dan } \\
\text { Zuniga- } \\
\text { Hansen, 2020 } \\
\end{array}$ \\
\hline \multirow{7}{*}{$\begin{array}{l}\text { Daging } \\
\text { Buah }\end{array}$} & \multirow{4}{*}{$\begin{array}{l}\text { Brown- } \\
\text { ies }\end{array}$} & 0 & & $2,46^{1}$ & $2,66^{1}$ & $3,13^{1}$ & $2,60^{1}$ & \multirow{4}{*}{$\begin{array}{c}\text { Moniharapo, } \\
\text { Picauly dan } \\
\text { Lelmalaya, } \\
2018\end{array}$} \\
\hline & & 25 & & $2,66^{1}$ & $3,30^{1}$ & $3,03^{1}$ & $3,16^{2}$ & \\
\hline & & 50 & & $2,33^{1}$ & $2,53^{12}$ & $2,83^{1}$ & $2,30^{1}$ & \\
\hline & & 75 & & $2,30^{1}$ & $2,03^{2}$ & $3,0^{1}$ & $2,13^{1}$ & \\
\hline & \multirow{3}{*}{$\begin{array}{l}\text { Sponge } \\
\text { Cake }\end{array}$} & 0 & & $7,49^{1}$ & $7,24^{1}$ & NT & $7,65^{1}$ & \multirow{3}{*}{$\begin{array}{l}\text { Segundo et } \\
\text { al., } 2017\end{array}$} \\
\hline & & 20 & $1-9$ & NT & NT & NT & NT & \\
\hline & & 40 & & $5,71^{2}$ & $6,17^{2}$ & NT & $5,64^{2}$ & \\
\hline \multirow[b]{2}{*}{ Kulit } & \multirow{2}{*}{$\begin{array}{l}\text { Bolu } \\
\text { cukke }\end{array}$} & 0 & & NT & NT & NT & NT & \multirow{2}{*}{$\begin{array}{c}\text { Manjilala, } \\
\text { Ekariskawati } \\
\text { dan Ipa, } 2019\end{array}$} \\
\hline & & 10 & & NT & NT & NT & NT & \\
\hline
\end{tabular}

Keterangan: Angka superscript yang berbeda pada baris yang sama menunjukkan perbedaan yang signifikan $(\alpha=5 \%)$.

Berdasarkan hasil sensori yang diperoleh (Tabel 6), menunjukkan hasil rasa dan tekstur produk roti panggang dengan penambahan tepung daging buah dan kulit pisang hijau memiliki hasil sensori tekstur rasa dan kesukaan keseluruhan yang dapat diterima serta disukai seperti produk roti kontrol karena menunjukkan nilai penerimaan yang tidak beda signifikan (Gomes, Ferreira dan Pimentel, 2016). Hasil sensori muffin memiliki rasa dan tektur yang lebih disukai dibandingkan dengan kontrol 
dengan nilai hedonik perlakuan sangat suka, namun untuk kesukaan keseluruhan lebih rendah dibanding kontrol (Soto-Maldonado, Concha-Olmos dan Zuniga-Hansen, 2020). Hasil sensori brownies memiliki rasa pada perlakuan penambahan tepung daging buah pisang dan kontrol menunjukkan hasil yang tidak berpengaruh nyata yang secara deskriptif memiliki rasa yang agak enak. Tekstur brownies dengan penambahan tepung daging buah pisang menunjukkan hasil yang agak lembut dan kesukaan keseluruhan yang diterima (Moniharapon, Picauly dan Lelmalaya, 2018).

Pengaruh penambahan tepung kulit pisang terhadap sensori tektur bolu cukke dapat diterima konsumen dan tidak menunjukkan perbedaan kesukaan terhadap bolu cukke perlakuan yang memiliki tekstur lembut, semakin tinggi penambahan tepung kulit pisang maka tingkat kesukaan rasa akan semakin menurun (Manjilala, Ekariskawati dan Ipa, 2019). Pengaruh penambahan tepung daging buah maupun kulit pisang akan memberikan warna yang semakin gelap pada semua produk dibandingkan dengan tanpa penambahan tepung pisang. Namun untuk produk brownies tidak berpengaruh nyata dalam perubahan warna karena dalam pembuatan brownies menggunakan cokelat bubuk (Moniharapon, Picauly dan Lelmalaya, 2018).

Pengaruh penambahan tepung daging buah maupun kulit pisang memberikan efek tekstur beberapa produk menjadi lebih keras (Loong dan Wong, 2018). Hal tersebut disebabkan karena proses gelatinisasi yang tidak sempurna dan kapasitas penyerapan air yang lebih tinggi, sehingga mendorong ketersediaan air untuk proses gelatinisasi menjadi rendah (Segundo et al., 2020). Perubahan warna menjadi lebih gelap pada produk dipengaruhi gula yang lebih tinggi dalam tepung pisang. Kandungan gula akan memicu terjadinya reaksi Maillard serta karamelisasi karena penggunaan suhu tinggi, sehingga berpengaruh pada bagian luar kue dan roti selama proses pemanggangan
(Segundo et al., 2017). Selain itu, disebabkan proses enzimatik dari tepung pisang yaitu oksidasi dengan udara yang dikatalisis oleh enzim fenol oksidasi atau polifenol oksidase (PPO) (Aryani, Mu'awanah dan Widyantara, 2020).

\subsection{Pengaruh penambahan tepung pisang (daging buah dan kulit) pada pengujian fisik produk roti dan kue}

Serat yang terkandung pada tepung pisang akan memengaruhi struktur roti dan kue terutama jumlah gluten yang ada. Adonan tidak dapat membentuk jaringan yang akan memberikan pengaruh mengembang. Selain itu, tidak dapat mempertahankan bentuk seperti pada roti tanpa penambahan tepung pisang (Gomes, Ferreira dan Pimentel, 2016) dan kue dibandingkan kontrol tanpa menggunakan tepung pisang (Tabel 7) (Segundo et al., 2017).

Semakin banyak konsentrasi penambahan tepung pisang (daging buah maupun kulit) akan menurunkan volume dari produk roti dan kue dibandingkan dengan hasil kontrol dengan tepung gandum. Penambahan tepung daging buah pisang pada produk mantou memiliki hasil yang meningkat pada perlakuan tepung pisang 130 dan tepung pisang 130 coffe. Hal ini terjadi karena perlakuan yang dilakukan menggunakan tepung daging buah pisang dengan konsentrasi yang sama, namun berbeda pada perlakuan penggunaan air yaitu penambahan air sebanyak $130 \%$ dan perlakuan penambahan kopi sebagai penyedap alami dan pewarna pada produk mantou (chinese steam bread) (Tabel 3).

Penambahan air yang berlebih pada roti sebesar 3-4\% akan melunakkan remah roti yang dikukus (Loong dan Wong, 2018). Presentase subtitusi tepung pisang yang digunakan $10-15 \%$ untuk menjaga daya terima produk (Martinez-Castano et al., 2020). Oleh karena itu, penggunaan tepung pisang hanya digunakan sebagai substitusi atau pengurangan dari tepung gandum. 
Tabel 7. Pengaruh penambahan tepung pisang terhadap volume roti dan kue

\begin{tabular}{|c|c|c|c|c|}
\hline Jenis Tepung & Jenis Roti & & Volume & Sumber \\
\hline \multirow{2}{*}{$\begin{array}{l}\text { Daging buah pisang } \\
\text { dan kulit }\end{array}$} & \multirow{2}{*}{$\begin{array}{l}\text { Roti Pang- } \\
\text { gang }\end{array}$} & $\begin{array}{l}\text { Kontrol } \\
(10 \%)\end{array}$ & $\begin{array}{l}6,99 \pm 0,32 \mathrm{~L} / \mathrm{kg}^{1} \\
5,46 \pm 0,31 \mathrm{~L} / \mathrm{kg}^{2}\end{array}$ & \multirow{2}{*}{$\begin{array}{c}\text { Gomes, } \\
\text { Ferreira dan } \\
\text { Pimentel, } 2016\end{array}$} \\
\hline & & $(20 \%)$ & $4,14 \pm 0,12 \mathrm{~L} / \mathrm{kg}^{3}$ & \\
\hline \multirow{3}{*}{ Daging buah pisang } & \multirow{2}{*}{$\begin{array}{l}\text { Mantou (Chi- } \\
\text { nese Steam } \\
\text { Bread) }\end{array}$} & $\begin{array}{l}\text { Kontrol } \\
\text { (TP100) } \\
\text { (TP130) }\end{array}$ & $\begin{array}{l}6,15 \pm 0,73 \mathrm{~mL} / \mathrm{g}^{1} \\
5,98 \pm 0,47 \mathrm{~mL} / \mathrm{g}^{1} \\
6,77 \pm 0,63 \mathrm{~mL} / \mathrm{g}^{1}\end{array}$ & \multirow[t]{2}{*}{$\begin{array}{l}\text { Loong dan } \\
\text { Wong, } 2018\end{array}$} \\
\hline & & (TP130Coffe) & $6,49 \pm 0,49 \mathrm{~mL} / \mathrm{g}^{1}$ & \\
\hline & Sponge Cake & $\begin{array}{l}\text { Kontrol } \\
(15 \%) \\
(30 \%)\end{array}$ & $\begin{array}{l}4,08 \mathrm{~cm}^{3} / \mathrm{g}^{1} \\
3,94-3,02 \mathrm{~cm}^{3} / \mathrm{g}^{1} \\
3,34-2,61 \mathrm{~cm}^{3} / \mathrm{g}^{2}\end{array}$ & $\begin{array}{c}\text { Segundoet al., } \\
2017\end{array}$ \\
\hline Kulit Pisang & Kue & $\begin{array}{l}\text { Kontrol } \\
(5 \%) \\
(10 \%) \\
(15 \%) \\
(20 \%)\end{array}$ & $\begin{array}{l}2,35 \pm 0,163 \mathrm{~cm}^{3} / \mathrm{g}^{1} \\
2,41 \pm 0,015 \mathrm{~cm}^{3} / \mathrm{g}^{1} \\
2,29 \pm 0,107 \mathrm{~cm}^{3} / \mathrm{g}^{12} \\
2,10 \pm 0,109 \mathrm{~cm}^{3} / \mathrm{g}^{23} \\
1,91 \pm 0,108 \mathrm{~cm}^{3} / \mathrm{g}^{3}\end{array}$ & $\begin{array}{l}\text { Turker et al., } \\
2016\end{array}$ \\
\hline
\end{tabular}

Keterangan : TP : tepung pisang

Keterangan: Angka superscript yang berbeda pada baris yang sama menunjukkan perbedaan yang signifikan $(\alpha=5 \%)$

Secara keseluruhan tepung kulit pisang mengandung lebih banyak serat pangan dibandingkan dengan tepung daging buah pisang (Khoozani, Birch dan Bekhit, 2019). Penggunaan kulit pisang dalam tepung akan memberikan pengaruh sensori produk yang lebih gelap dan memberikan rasa yang sepat dibandingkan dengan tepung pisang tanpa kulit (De Gouveia dan Zandonadi, 2013). Penggunaan tepung pisang (daging maupun kulit) dengan tingkat pematangan yang berbeda tidak mempengaruhi hasil serat pangan pada varietas secara konsisten (Emaga et al., 2008). Secara keseluruhan dapat direkomendasikan penggunaan tepung pisang daging buah dan kulit pisang untuk diaplikasikan pada produk roti dan kue, sehingga dapat memberikan peningkatan gizi terutama serat pangan.

\section{KESIMPULAN}

Berdasarkan hasil studi literatur dari beberapa sumber dapat diketahui bahwa daging buah pisang dan kulitnya dapat diolah menjadi tepung pisang sebagai substitusi tepung gandum, sehingga dapat diaplikasikan pada berbagai macam produk pangan

terutama roti dan kue yang dapat meningkatkan nilai gizi. Penambahan tepung pisang (daging buah maupun kulit) dengan konsentrasi yang semakin tinggi akan menurunkan kualitas roti dan kue. Tepung pisang (daging buah maupun kulit) dapat diaplikasikan pada produk pangan dengan konsentrasi $10-15 \%$ untuk menjaga sifat sensori dan fisik roti dan kue.

\section{UCAPAN TERIMA KASIH}

Terima kasih kepada semua pihak yang telah memberikan kontribusi dalam penyusunan Literatur review ini, sehingga Literature Review ini dapat tersusun dengan baik.

\section{DAFTAR PUSTAKA}

Adebayo-Oyetoro, A. O., Ogundipe, O. O., \& Adeeko, K. N. (2016). Quality assessment and nmconsumer acceptability of bread from wheat and fermented banana flour. Food Science \& Nutrition, 4(3), 364-369. https://doi.org/10.1002/fsn3.298

Adi, D. D., Oduro, I. N., \& Tortoe, C. (2019). Physicochemical changes in 
plantain during normal storage ripening. Scientific African, 6, e00164. https://doi.org/10.1016/j.sciaf.2019.e00 164 2468-2276/

Alkarkhi, A. F., bin Ramli, S., Yong, Y. S., \& Easa, A. M. (2011). Comparing physicochemical properties of banana pulp and peel flours prepared from green and ripe fruits. Food Chemistry, 129(2), 312-318. https://doi.org/10.1016/j.foodchem.201 1.04.060

Aryani, T., Mu'awanah, I. A. U., \& Widyantara, A. B. (2020). Kajian fitokimia dan proksimat tepung kulit pisang musa sapientum dan uji organoleptik pada donat. Gizi Indonesia, $\quad 43(1), \quad 1-10$. https://doi.org/10.36457/gizindo.v43i1. 285

Baba, M. D., Manga, T. A., Daniel, C., \& Danrangi, J. (2015). Sensory evaluation of toasted bread fortified with banana flour: A preliminary study. American Journal of Food Science and Nutrition, 2(2), 9-12.

De Gouveia, P. F., \& Zandonadi, R. P. (2013). Green banana: New alternative for gluten-free products. Agro Food Industry Hi-Tech, 24(3), 49-52.

Dhingra, D., Michael, M., Rajput, H., \& Patil, R. T. (2012). Dietary fibre in foods: A review. Journal of Food Science and Technology, 49(3), 255266. https://doi.org/10.1007/s13197011-0365-5

Emaga, T. H., Robert, C., Ronkart, S. N., Wathelet, B., \& Paquot, M. (2008). Dietary fibre components and pectin chemical features of peels during ripening in banana and plantain varieties. Bioresource Technology, 99(10), 4346-4354. https://doi.org/10.1016/j.biortech.2007. 08.030

Fatemeh, S. R., Saifullah, R., Abbas, F. M. A., \& Azhar, M. E. (2012). Total phenolics, flavonoids and antioxidant activity of banana pulp and peel flours: Influence of variety and stage of ripeness. International Food Research Journal, 19(3), 1041.

Gomes, A. A. B., Ferreira, M. E., \& Pimentel, T. C. (2016). Bread with flour obtained from green banana with its peel as partial substitute for wheat flour: Physical, chemical and microbiological characteristics and acceptance. International Food Research Journal, 23(5), 2214-2222.

Guessan, A., A., Kouadio, O. K., \& Gonnety, J., T. (2018). Effect of chemical and thermal treatments on browning Inhibition of senescent plantain ( musa paradisiaca) puree for semolinas preparation,. $\quad 8(4), \quad 75-84$. https://doi.org/10.5923/j.ajb.20180804. 02

Hardisari, R., \& Amaliawati, N. (2016). Manfaat prebiotik tepung pisang kepok (musa paradisiaca formatypica) terhadap pertumbuhan probiotik lactobacillus casei secara in vitro. Jurnal Teknologi Laboratorium, 5(2), 64-67.

Imam, M. Z., \& Akter, S. (2011). Musa paradisiaca 1. And musa sapientum 1.: A phytochemical and pharmacological review. Journal of Applied Pharmaceutical Science, 1(5), 14-20.

Khoozani, A. A., Birch, J., \& Bekhit, A. E.D. A. (2019). Production, application and health effects of banana pulp and peel flour in the food industry. Journal of Food Science and Technology, $56(2)$,

548-559.

https://doi.org/10.1007/s13197-01803562-z

Khoozani, A. A., Birch, J., \& Bekhit, A. E.D. A. (2020). Textural properties and characteristics of whole green banana flour produced by air-oven and freezedrying processing. Journal of Food Measurement and Characterization, 110. https://doi.org/10.1007/s11694020-00402-7

Khoozani, A., Kebede, B., Birch, J., \& Bekhit, A. E.-D. A. (2020). The effect of bread fortification with whole green banana flour on its physicochemical, 
nutritional and in vitro digestibility. Foods, 9(2), 1-11. https://doi.org/10.3390/foods9020152

Loong, C. Y. L., \& Wong, C. Y. H. (2018). Chinese steamed bread fortified with green banana flour. Food Research, 2(4), 320-330. https://doi.org/10.26656/fr.2017.2(4).0 58

Malik, S., Khanam, T., Ashwal, L., Gururani, P., \& Rathi, N. (2006). Pomace: A potential ingredient of cake making a review paper. The Pharma Innovation Journal, 8(5), 7.

Manjilala, M., Ekariskawati, E., \& Ipa, A. (2019). Daya terima bolu cukke substitusi tepung kulit pisang dan tepung tempe pada balita gizi kurang. Media Gizi Pangan, 26(1), 71-77. https://doi.org/10.32382/mgp.v26i1.43 0

Mardiah, E. (2011). Mekanisme inhibisi enzim polifenol oksidase pada sari buah markisa dengan sistein dan asam askorbat. Jurnal Riset Kimia, 4(2), 3237.

https://doi.org/10.25077/jrk.v4i2.126

Martinez-Castano, M., Lopera-Idarraga, J., Pazmiño-Arteaga, J., \& GallardoCabrera, C. (2020). Evaluation of the behaviour of unripe banana flour with non-conventional flours in the production of gluten-free bread. Food Science and Technology International, 26(2), 160-172. https://doi.org/10.1177/1082013219873 246

Mohapatra, D., Mishra, S., \& Sutar, N. (2010). Banana and its by-product utilisation: An overview.

Moniharapon, E., Picauly, P., \& Lelmalaya, L. (2018). Kajian sifat kimia dan organoleptik brownies pisang tongka langit. AGRITEKNO: Jurnal Teknologi Pertanian, 7(2), 60-63. https://doi.org/10.30598/jagritekno.201 8.7.2.60

Mudgil, D. (2017). The interaction between insoluble and soluble fiber. In Dietary fiber for the prevention of cardiovascular disease (pp. 35-59). Elsevier.

Pereira, A., \& Maraschin, M. (2015). Banana (musa spp) from peel to pulp: Ethnopharmacology, source of bioactive compounds and its relevance for human health. Journal of Ethnopharmacology, 160(1), 149-163. https://doi.org/10.1016/j.jep.2014.11.00 8

Quagliani, D., \& Felt-Gunderson, P. (2017). Closing america's fiber intake gap: Communication strategies from a food and fiber summit. American Journal of Lifestyle Medicine, 11(1), 80-85. https://doi.org/10.1177/1559827615588 079

Ramli, S., Alkarkhi, A. F., Shin Yong, Y., Min-Tze, L., \& Easa, A. M. (2009). Effect of banana pulp and peel flour on physicochemical properties and in vitro starch digestibility of yellow alkaline noodles. International Journal of Food Sciences and Nutrition, 60((S4)), 326340.

https://doi.org/10.1080/0963748090318 3503

Salih, Z. A., Siddeeg, A., Taha, R. T., Bushra, M., Ammar, A.-F., \& Ali, A. O. (2017). Physicochemical and functional properties of pulp and peel flour of dried green and ripe banana (cavendish). International Journal of Research in Agricultural Sciences, 4(6), 348-353.

Segundo, C., Giménez, A., Lobo, M., Iturriaga, L., \& Samman, N. (2020). Formulation and attributes of glutenfree cakes of andean corn improved with green banana flour. Food Science and Technology International, 26(2), 95-104.

https://doi.org/10.1177/1082013219860 361

Segundo, C., Román, L., Gómez, M., \& Martínez, M. M. (2017). Mechanically fractionated flour isolated from green bananas ( $m$. Cavendishii var. Nanica) as a tool to increase the dietary fiber and phytochemical bioactivity of layer 
and sponge cakes. Food Chemistry, Yuliana, R., Kusdiyantini, E., \& Izzati, M. 219, 240-248. (2014). Potensi tepung umbi dahlia dan https://doi.org/10.1016/j.foodchem.201 6.09.143

Segundo, C., Román, L., Lobo, M., Martinez, M. M., \& Gómez, M. (2017). Ripe banana flour as a source of antioxidants in layer and sponge cakes. Plant Foods for Human Nutrition, 72(4), 365-371. https://doi.org/10.1007/s11130-0170630-5 ekstrak inulin dahlia sebagai sumber karbon dalam produksi fruktooligosakarida (fos) oleh khamir kluyveromyces marxianus ducc-y-003. Bioma: Berkala Ilmiah Biologi, 16(1), 39-49. https://doi.org/10.14710/bioma.16.1.39 $-49$

Soto-Maldonado, C., Concha-Olmos, J., \& Zúniga-Hansen, M. E. (2020). The effect of enzymatically treated ripe banana flour on the sensory quality and glycemic response of banana-wheat flour composite muffins. Journal of Food Science and Technology, 57(1), 3621-3627.

https://doi.org/10.1007/s13197-02004394-6

Turker, B., Savlak, N., \& Kaşıkcı, M. B. (2016). Effect of green banana peel flour substitution on physical characteristics of gluten-free cakes. Current Research in Nutrition and Food Science Journal, 4(S2), 197-204. https://doi.org/10.12944/CRNFSJ.4.Sp ecial-Issue-October. 25

Vu, H. T., Scarlett, C. J., \& Vuong, Q. V. (2017). Effects of drying conditions on physicochemical and antioxidant properties of banana (musa cavendish) peels. Drying Technology, 35(9), 1-34. https://doi.org/10.1080/07373937.2016. 1233884

Wardhani, D. H., Yuliana, A. E., \& Dewi, A. S. (2016). Natrium metabisulfit sebagai anti-browning agent pada pencoklatan enzimatik rebung ori (bambusa arundinacea). Jurnal Aplikasi Teknologi Pangan, 5(4), 140-145. https://doi.org/10.17728/jatp.202 